\title{
Wavelet Coherence as a Research Tool for Stability of the Banking System (The Example of Ukraine)
}

\author{
Nataliia Pogorelenko1, Vyacheslav V. Lyashenko², Mohammad Ayaz Ahmad ${ }^{3 *}$ \\ ${ }^{1}$ Kharkiv Institute of Banking of the University of Banking of the National Bank of Ukraine, Kharkiv, Ukraine \\ ${ }^{2}$ Department of Informatics, Kharkiv National University of Radio Electronics, Kharkiv, Ukraine \\ ${ }^{3}$ Physics Department, Faculty of Science, University of Tabuk, Tabuk, Saudi Arabia \\ Email: *mayaz.alig@gmail.com
}

Received 17 July 2016; accepted 9 August 2016; published 12 August 2016

Copyright (C) 2016 by authors and Scientific Research Publishing Inc.

This work is licensed under the Creative Commons Attribution International License (CC BY).

http://creativecommons.org/licenses/by/4.0/

(c) (i) Open Access

\begin{abstract}
The banking system presents an open, multifaceted and meaningful set of different institutional units within a single monetary market. The effectiveness of such a system also largely determines the set of continuous mobilities of financial flows, and the result should determine the stability of the banking system. Accordingly, the work reveals a set of indicators of banking system stability and expediency analysis of available values using wavelet analysis. Wavelet coherence is considered as a tool for wavelet analysis. Based on the analysis we display the impacts on the stability of the banking system in Ukraine in 2005-2015 years.
\end{abstract}

\section{Keywords}

Stability of the Banking System, Banking, Wavelet Coherence, Time Series, Frequency-Temporal Area

\section{Introduction}

The banking system in any country is one of the key elements of its overall monetary mechanism. This is a resolution of the banking system to accumulate and redistribute available financial resources across sectors and undertakings (Mohammad Ayaz Ahmad, Grigoriy Kots and Vyacheslav Lyashenko [1]), and also the ability to generate additional resources, generate leverage for their mobility and ability to evolve and mutate (Ahmed Arif and Ahmed Nauman Anees [2], Bruno and Shin [3]). So one of the issues of effective functioning of the banking

\footnotetext{
${ }^{*}$ Corresponding author.
}

How to cite this paper: Pogorelenko, N., Lyashenko, V.V. and Ahmad, M.A. (2016) Wavelet Coherence as a Research Tool for Stability of the Banking System (The Example of Ukraine). Modern Economy, 7, 955-965.

http://dx.doi.org/10.4236/me.2016.79098 
system can be defined as a coherent and balanced dynamics of financial flows or the banking system is formed under the influence of its actions in terms of achieving compliance and functional limitations that put on such a system (Alexander Kuzemin and Vyacheslav Lyashenko [4]).

Structurally, the banking system, especially in countries with developed market economies, consists of toplevel represented the Central Bank and several commercial banks acting in accordance with the existing leverage of the central bank and thus determines a lower level hierarchical structure corresponding bank system (Camelia Minoiu and Javier A. Reyes [5]). Functional interaction between different structural levels of the banking system and within individual levels is determined according to the mobility of incoming and outgoing cash flows generated by the banking system and acts on other financial flows within the overall monetary mechanism of a country. Therefore it is important to take into account the overall coherence and balance of financial flows that determine the effectiveness of monetary mechanism, which is directly examined. However, according to the functional orientation of the banking system, achieving overall coherence and balance of financial flows that determine the effectiveness of the monetary mechanism of the country largely depends on stable operation, being stability of the banking system. Stability of the banking system itself is derived from consistency of its incoming and outgoing cash flows, and the result is reflected in certain indicators of effectiveness of the banking system.

So we come to consider the importance of indicators of the banking system, reflecting the availability of its manifestations and opportunities for stable and sustainable operation. At the same time the need for such consideration is determined in terms of the proper functioning of the banking system and ensures continuous efficiency of the monetary mechanism of the banking system which is investigated.

\section{The Set of Indicators of Financial Stability of the Banking System and Peculiarities of Their Use in Empirical Studies}

The basis of the disclosure of financial stability of the banking system first determines the consistency and balance of incoming and outgoing financial flows of the system, a reflection of what is important indicators: amount and structure of loans, the volume and structure of borrowed funds on deposit accounts, the amount of equity capital, interest rates and so on. According to the mentioned above and according to general method of International Monetary Fund on the disclosure of financial stability, the key indicators of banking system stability include [6]:

indicators of banking activity on the basis of capital that allow us to determine, first, the ability of the banking system self-defense and self-regulation in the presence of capital adequacy, its agility and successful application in the field of banking activity. These indicators include [6]: the ratio of regulatory capital to risk-weighted assets, ratio of regulatory capital to risk-weighted assets, ratio of capital to assets, ratio of non-performing loans net of provisions to capital ratio of net income to average equity, ratio of large open positions to equity, ratio of net open position foreign exchange capital, ratio of gross positions in financial derivatives from the assets and liabilities to capital, ratio of net open positions in instruments of equity capital;

indicators of banking based on assets that can determine the focus and efficiency of investment funds that were accumulated from the banking system and allow you to uncover and identify the components achieve banking stability (or vice versa bottlenecks to ensure banking stability). These indicators include [6]: ratio of liquid assets to total assets, ratio of liquid assets to short term liabilities, ratio of customer deposits to total gross loans (excluding interbank), ratio of net income to average total assets, ratio of non-performing loans to total gross loans ratio of loans by sector to total gross loans, ratio of loans to mine real estate to total loans, ratio of loans for commercial real estate to total loans, ratio of loans by geographic distribution to total gross loans, ratio of foreign currency loans to total gross loans, ratio of foreign currency liabilities to total liabilities;

indicators of banking activity, defined on the basis of income and expenses. These allow us to discover and identify existing conditions to ensure and maintain stability of the banking system taking into account the impacts on the implementation of the relevant kind of economic activity-banking. These indicators include [6]: ratio of interest income on gross income, ratio of trade income to total income, ratio of non-interest expenses to gross income, the cost of maintaining the staff to non-interest expenses;

indicators of banking activity, taking into account the interest rates on borrowed funds and funds at the disposal of banks respectively. These allow us to take into account the available existing conditions to ensure and maintain the stability of the banking system. These indicators include [6]: the spread between the base rate on loans and deposits, the spread between the highest and lowest interbank rates. 
Thus, the disclosure of the content essence of financial stability of the banking system is based on a consideration of the totality of incoming and outgoing financial flows summarized by a number of indicators of banking activity (Figure 1).

However, the specifics of banking activity in individual countries based on a possible set of existing indicators of generalization of mobility of certain financial flows allow selecting individual approaches to disclosure of relevant banking stability. Among these features the focus on mobility indicators of the financial flows associated with foreign exchange transactions or real estate transactions should be noted. These features are particularly characteristic for transition countries where significant transformation and realignment of economic relations take place (Yuriy Gorodnichenko and Monika Schnitzer [7], Pierre-Olivier Gourinchas and Olivier Jeanne [8]). Thus the existing set of indicators of banking stability is divided into basic and advanced. This allows considering both general trends in the banking system of individual countries in terms of classical determinants achieve banking stability and features such as the development at a certain time interval.

For a detailed analysis of the existing conditions of security and achieving stability of the banking system researchers usually use some statistical methods of data analysis on selected indicators of banking. This allows you to emphasize the importance of the chosen study (according to statistics and methods of analysis) and point out the features of stability of the banking system on relevant provisions (values available on selected indicators from the analysis of banking activities).

In particular, Ines Andrea Ati, analyzing the stability of the banking system in Tunisia focuses on the quality of the loan portfolio of banks in general to determine the effect of the structure of banks' balance sheets on the stability of their development in terms of combating negative phenomena in the financial sector [9]. In addition, one of the components of a possible review of indicators of sustainable development of the banking system on the basis of the quality of loans is the weighted approach to credit risk assessment on areas of distribution of available resources of the bank. Relevant research is based on statistical calculations of separate indices to assess fluctuations in total value of loans, loans that are returned on time and credits that are problematic [9].

Equally important in relation to the issue of stability of the banking system is a review of the interest rates. This is connected with a comparison of mobility of incoming and outgoing cash flows of the banking system, and the development of the banking system in the conditions of competition between the various entities. As an example, on summarizing the relevant area of research lately, we recommend studies of Jin-feng She and Mei-xia Li [10], Hong Liu, Phil Molyneux and John Wilson [11], Klaus Schaeck and Martin Cihák [12]. These researchers define the basis of the construction of various econometric models that allow you to not only consider the existing conditions of competition among banks and its impact on the stability of the banking system, but also to identify the most important conditions for the formation of an environment for the development of the banking system.

At the same time Ke Wang, Wei Huang, Jie Wu and Ying-Nan Liu conduct research on stability of the banking system based on the methodology DEA [13]. This allows determining specific measures to improve the stability of the banking system and point out the bottlenecks that hinder the development of banking.

Deniz Anginer and Asli Demirguc-Kunt pay attention to the variability of financial stability over time [14]. This allows you to ascertain the need and importance of taking into account the time factor in the disclosure of banking system stability, and thus operate relevant time series for such disclosure.

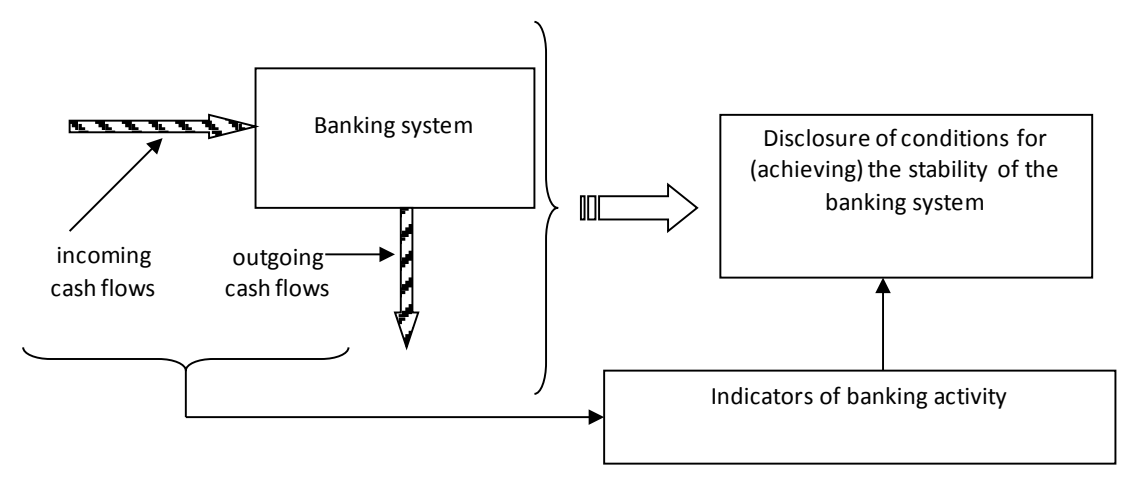

Figure 1. Financial flows and indicators of banking activity in the disclosure of banking system stability. 
So we can note the diversity of analysis and study of determining the stability of the banking system, which is basically based on time series data on selected indicators of disclosure of such stability. But also worth emphasizing that the current study did not sufficiently take into account the results of cross-analysis with determining and disclosing displays the current stability of the banking system.

However, the use of different methods and approaches to the analysis of the stability of the banking system can expand limits of proper analysis and get new results. Due to such a generalization we propose to focus on discovering the stability of the banking system by the methods of wavelet analysis. Disclosure of available content of stability of the banking system will be produced according to the generalized cross-analysis between time series data that determine or are individual components of such stability. This is what defines the basis for the purpose of this study.

\section{Wavelet Analysis Methodology as a Tool to Study Time Series}

In general, wavelet analysis methodology allows for the selected schedule time series system of individual wavelets. These wavelets may be obtained by shifting and scaling so-called function-generating wavelet [15]. Therefore, in this case, wavelet is a function which rapidly decreases at infinity and whose average value is zero.

The basis of formal generalization of continuous wavelet transformation on the time interval $t$ is converting the input time series $x(t) \in L^{2}(R)$ using wavelet parent $\phi(t)$ [15]-[17]:

$$
W_{x}(u, s)=\int_{-\infty}^{+\infty} x(t) \frac{1}{\sqrt{s}} \phi\left(\frac{t-u}{s}\right),
$$

where $\frac{1}{\sqrt{s}}$ denotes a normalization,

$u$ is a location parameter,

$s$ is a scale parameter,

$$
\int_{-\infty}^{\infty} \phi(t) \mathrm{d} t=0 .
$$

In this case, feasibility of wavelet analysis in time series study is determined by the fact that the method of wavelet analysis allows to discover the local features of the studied time series due to the decomposition of the input data [17] [18]. That is, the wavelet transformation defines the hierarchical structure of the input of the studied time series. Underlying this statement is the fact that information flows, generated by fractal time series have properties detected by wavelet transform, making it even more informative [19]. Then wavelet transform allows adding input characteristics of time series that are investigated.

In addition, the empowerment of study time series using wavelet analysis methodology promotes the use of various procedures of wavelet transformation: even-scaled analysis, cross wavelet transformation, wavelet coherence. Then wavelet analysis methodology has been widely used in the disclosure of dynamics of time series that define various economic data [20] [21].

One of the main wavelet transformation methods used for generalized cross-reference analysis between different time series is wavelet coherence. It allows calculating local correlation of two time series in a region of time-frequency. It uses the following formalized model: wavelet coherence as the squared absolute value of the smoothed cross wavelet spectra $W_{x y}(u, s)$ (time $(x)$ and frequency $(y)$ of the time series), normalized by the product of the smoothed individual wavelet power spectra of each series [22] [23]:

$$
R^{2}(u, s)=\frac{\left|Q\left(s^{-1} W_{x y}(u, s)\right)\right|}{Q\left(s^{-1}\left|W_{x}(u, s)\right|^{2}\right) Q\left(s^{-1}\left|W_{y}(u, s)\right|^{2}\right)},
$$

where $Q$ is a smoothing operator.

We use Morlet wavelet that is a complex wavelet with a good time-frequency localization, as a parent one [22] [23].

The squared wavelet coherency coefficient is in the range $0 \leq R^{2}(u, s) \leq 1$, values close to zero indicate weak correlation, while values close to one are evidences of strong correlation. 
Thus, wavelet coherency analysis enables interconnection between the studied time series and analyzes the frequency of such communications.

\section{Data for the Analysis}

For the analysis we will use relevant data for the banking system of Ukraine. This choice is made due to the need for a synthesis of the analysis in terms of the banking system of Ukraine, accompanied by significant and sudden changes in the political system of Ukraine for many years, due to the global changes taking place in the banking system of Ukraine in recent years.

The main objective of the analysis of the stability of the banking system in Ukraine is, above all, the comparison of certain indicators of such stability and determining the dynamics of their consistency with each other over time. That is, we try to answer the question: how fully and adequately some indicators reflect the current state of the stable functioning of the banking system in Ukraine.

As some pairs of indicators for appropriate analysis we consider:

the ratio of non-performing loans excluding capital reserves (KK) and the ratio of non-performing loans to total gross loans (KVK); the rate of return on assets (PA) and the rate of return on capital (PK); the ratio of interest margin to gross income (MD) and the ratio of non-interest expenses to gross income (ND); the ratio of liquid assets to total assets (LA) and the ratio of liquid assets to current liabilities (LZ); the ratio of trading income to gross income (TD) and the ratio of staff costs to non-interest expenses (VP); the spread between rates on loans and deposits (PKD) and the spread between the highest and lowest interbank rates (KD); the spread between rates on loans and deposits (PKD) and the ratio of customer deposits to total gross loans (excluding interbank) (VKD).

The above selection of individual indicators was made in accordance with their importance and corresponds with mobility of inward and outward flows as well as with available methodological foundations of stability disclosure. Grouping selected indicators of stability of the banking system is determined by the ability of conducting comparative and crossed correlation of effects between financial flows of the banking system and bringing coherence between these flows or installation on problematic aspects of banking activity.

In particular, the ratio of non-performing loans excluding capital reserves and the ratio of non-performing loans to total gross loans identifies and maps a dynamic display of the current stability of the banking system in Ukraine under the existing conditions for banking, comparison of the rate of return on assets and rate of return on capital can reveal the conditions of the stability of the banking system in Ukraine to the efficiency of banking activities according to indicators such as assets and capital, the ratio of trading income to gross income and the ratio of staff costs non-interest expenses to determine expression stability of the banking system in Ukraine by the performance of the personnel of banks, the spread between rates on loans and deposits (basis points) and the spread between the highest and lowest interbank rates (basis points), determine the conditions of stability of the banking system in Ukraine in accordance with the balance set interest rates according to the circumstances of their formation on the market, the spread between rates on loans and deposits (basis points) and the ratio of customer deposits to total gross loans (excluding interbank), reveals signs of stability of the banking system in Ukraine by the volume and terms of attracting and allocation of resources of the banking system.

As the time interval for the study of indicators on stability of the banking system in Ukraine we selected data for the period Q4 2005-Q4 2015. So we have 41 values for each data series. Each of the values is appropriate for data specific indicator of stability at quarter end from the selected time period. This allows you to take into account the different periods of the banking system in Ukraine in terms of ensuring its stability.

All data for analysis was taken from the official website of the regulator of banking activities in Ukraine-the National Bank of Ukraine (http://www.bank.gov.ua-statistics of indicators of financial stability). Table 1 shows generalized statistical data that characterizes indicators chosen for the study.

\section{Findings and Discussion}

On Figure 2, Figure 3, Figures 5-9 you can check the results of wavelet coherence between selected indicators for the study on stability of the banking system in Ukraine. Each of the following figures indicated a separate group of indicators that match each other. This comparison of selected groups of indicators is displayed in the time-frequency plane. Horizontal axis shows time scale, which corresponds to the sequence analyzed data since the $4^{\text {th }}$ quarter of 2005 and ending with Q4 2015. On the vertical axis are the weighted characteristics of the 


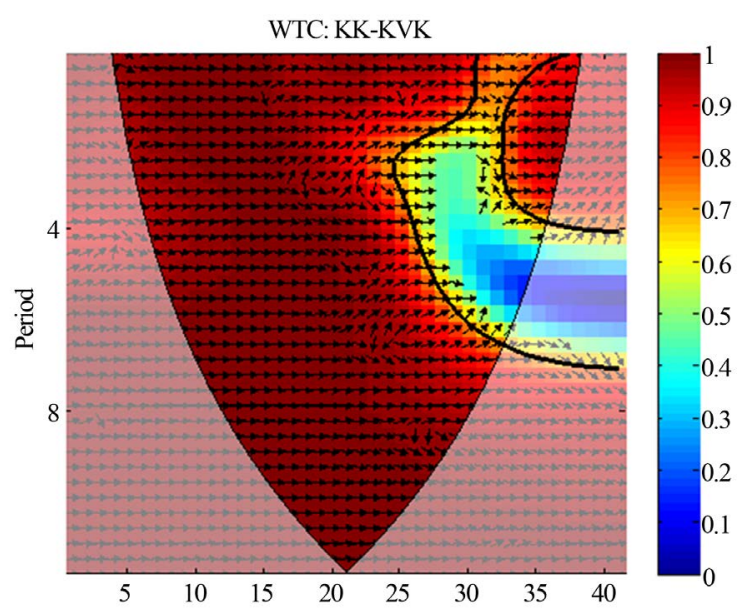

Figure 2. Wavelet coherence between KK and KVK.

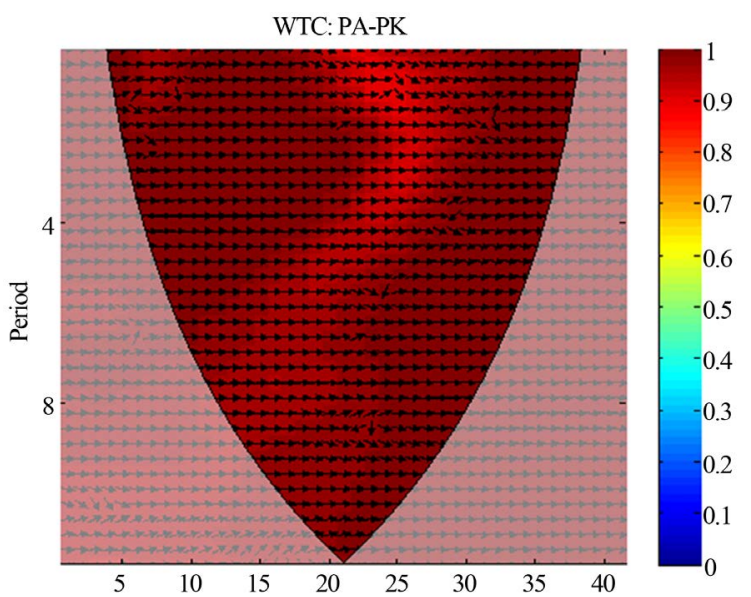

Figure 3. Wavelet coherence between PA and PK.

Table 1. Statistical indicators of data series that define the selected set of indicators on stability of the banking system in Ukraine.

\begin{tabular}{ccccccccc}
\hline \multirow{2}{*}{$\begin{array}{c}\text { Stability } \\
\text { indicators }\end{array}$} & \multicolumn{9}{c}{ Statistical data } \\
\cline { 2 - 8 } KK & Minimum & Maximum & Average & Median & Standard deviation & Excess & Asymmetry \\
KVK & 2.440 & 378.520 & 106.202 & 31.970 & 132.081 & -0.137 & 1.294 \\
PA & -23.530 & 2.100 & -1.201 & 0.260 & 18.424 & -0.222 & 1.127 \\
PK & -277.330 & 17.820 & -13.652 & 1.720 & 4.604 & 13.920 & -3.331 \\
MD & 14.200 & 71.010 & 57.460 & 58.560 & 10.32 .327 & 16.868 & -3.817 \\
ND & 36.630 & 70.470 & 59.967 & 61.000 & 6.567 & 6.575 & -1.927 \\
LA & 9.350 & 33.000 & 18.532 & 18.890 & 5.795 & -0.278 & 0.345 \\
LZ & 30.950 & 100.850 & 67.920 & 83.800 & 26.881 & -1.884 & -0.300 \\
TD & 2.120 & 52.130 & 8.860 & 7.000 & 8.514 & 16.498 & 3.554 \\
VP & 35.240 & 51.540 & 43.145 & 43.210 & 4.824 & -0.884 & 0.063 \\
PKD & 354.000 & 892.000 & 602.766 & 575.000 & 125.760 & -0.333 & 0.373 \\
KD & 594.000 & 14990.000 & 2903.547 & 2390.000 & 2700.092 & 10.097 & 2.820 \\
VKD & 43.140 & 95.050 & 64.289 & 64.860 & 11.660 & 0.465 & 0.231 \\
\hline
\end{tabular}


analyzed data series in frequency space measuring their results are grouped by time periods (quarters) according to the total time interval. Along each of the figures importance scale is presented as separate columns for reflections. Defined lines are a manifestation of localization for individual irregularities within studied time series according to importance of irregularities. In general, each point of wavelet reflects shown in Figure 2, Figure 3, Figures 5-9 is their value in the time-frequency space, which are calculated through wavelet transformation. The phase difference, indicated by arrows, gives us details about delays of oscillation of the two examined time series. Arrows pointing to the right (left) when the time series are in-phase (anti-phase) or are positively (negatively) correlated. Arrow pointing up means that the first time series leads the second one, arrow pointing down indicates that the second time series leads the first one.

Therefore, Figure 2 shows that over a longer period of time investigated there is a steady mutual tendency between ratio of non-performing loans excluding capital reserves $(\mathrm{KK})$ and the ratio of non-performing loans to total gross loans (KVK). The manifestation of breach of reciprocity between the ratio of non-performing loans excluding capital reserves (KK) and the ratio of non-performing loans to total gross loans (KVK) begins to be determined on the basis of the banking system in Ukraine in the $1^{\text {st }}$ quarter of 2012. That is 1 quarter of 2012 should be considered the point of departure, when the stability of the banking system is impaired due to lack of capital as a factor of stability and respect for this increase in non-performing loans.

From the data in Figure 3 above all we can see quite identical consistency and reciprocity between the rate of return on assets (PA) and the rate of return on capital (PK). However, given the downward trend as the of values of return on assets (PA) (in Figure 4) and also of values the rate of return on capital (PK) it is worth noting that in terms of wavelet coherence manifestation of instability of banking system is evident.

According to Figure 5 you can talk about lack of complete consistency between the ratio of interest margin to

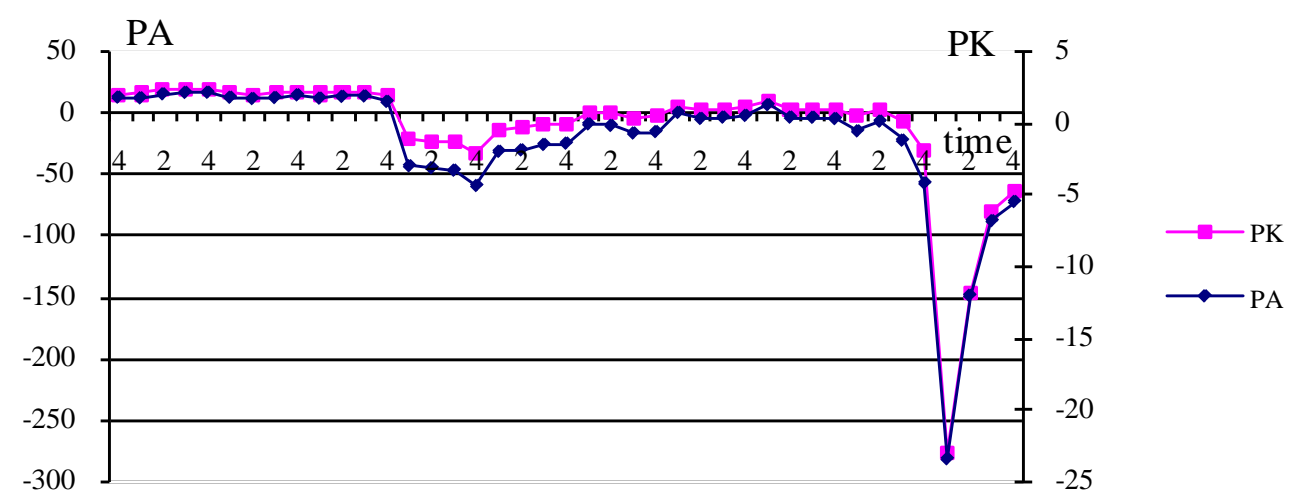

Figure 4. Dynamics of values for rate of return on assets (PA) and the rate of return on capital (PK) for the banking system in Ukraine in Q4 2005-Q4 2015.

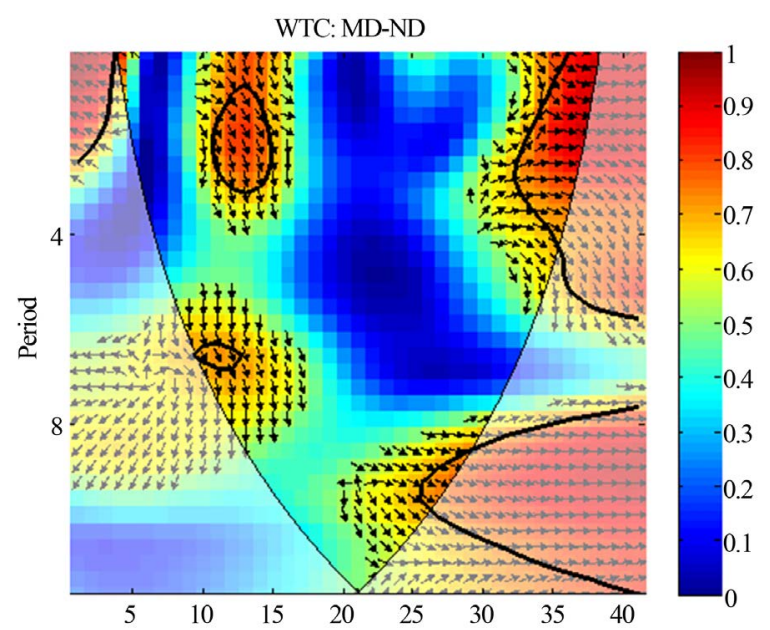

Figure 5. Wavelet coherence between MD and ND. 
gross income (MD) and the ratio of non-interest expenses to gross income (ND). Therefore, it is worth noting the fact that in terms of the banking system in Ukraine there may be a lack of balance between the margin and non-interest expenses. This may be an evidence of lack of manifestation of prudential policy for setting remuneration of banking activities in the form of interest or in the form of commission income and expenses. So the dynamics of the analyzed data series and analysis of such dynamics based on wavelet coherence can be seen as a negative factor to determine the stability of the banking system in Ukraine.

Lack of consistency in analyzed data series is observed in terms of the ratio of liquid assets to total assets (LA) and the ratio of liquid assets to current liabilities (LZ) (Figure 6). This fact can be considered in terms of lack of liquid assets in case of urgent necessity to repay short-term obligations. Therefore it is also necessary to take disclosing weight stability of the banking system into account.

In addition, the relevant data from the analysis of wavelet coherence between the ratio of trading income to gross income (TD) and the ratio of staff costs to non-interest expenses (VP) (Figure 7) can be seen as a manifestation of a lack of balance in staff costs to a result which such expenses determined in terms of one of the areas forming gross income. So there definitely is a lack of conformity of productivity of its workers to costs that are aimed at keeping staff. Therefore, it is also necessary to identify this issue as one of the factors affecting the stability of the banking system.

According to the data in Figure 8 we should also note that in Ukraine spread between rates on loans and deposits in general is different from the general trend of the corresponding spread that sets the interbank market.

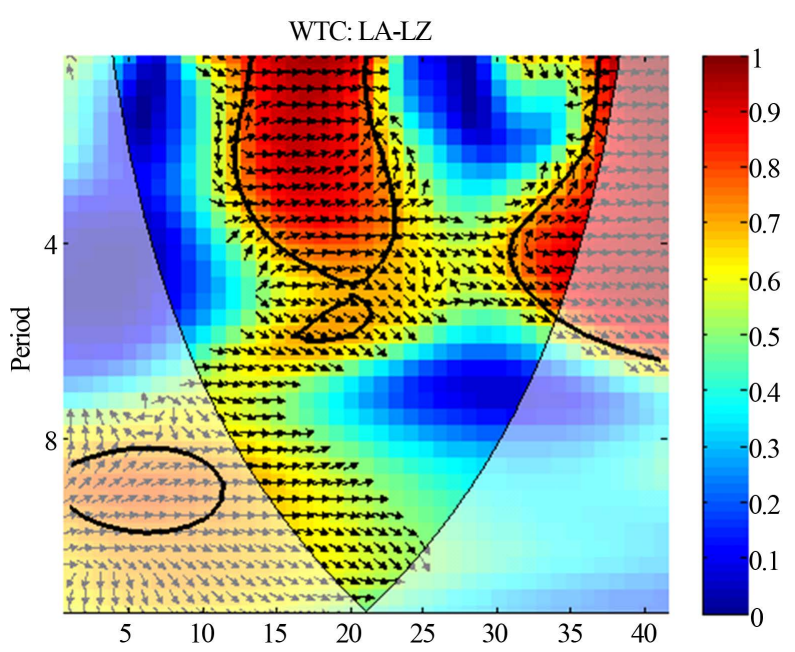

Figure 6. Wavelet coherence between LA and LZ.

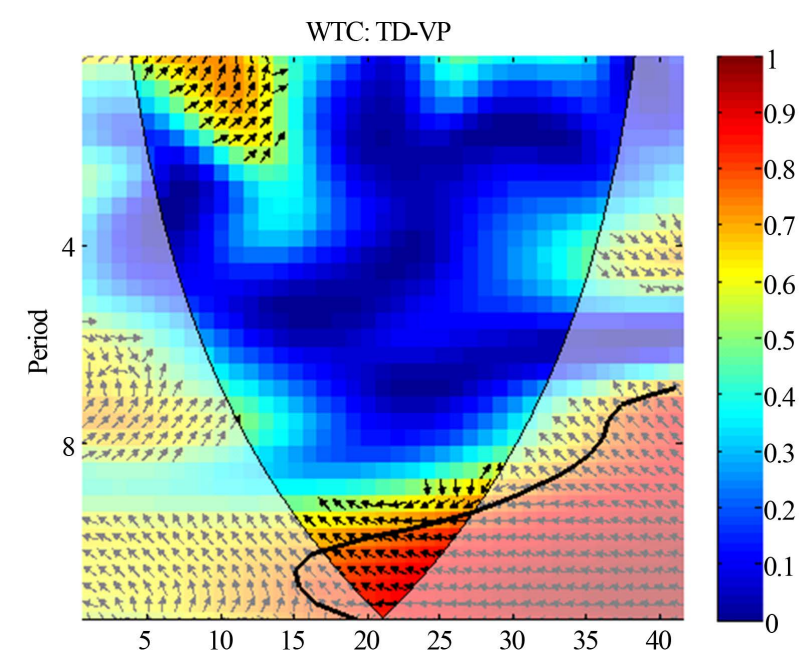

Figure 7. Wavelet coherence between TD and VP. 


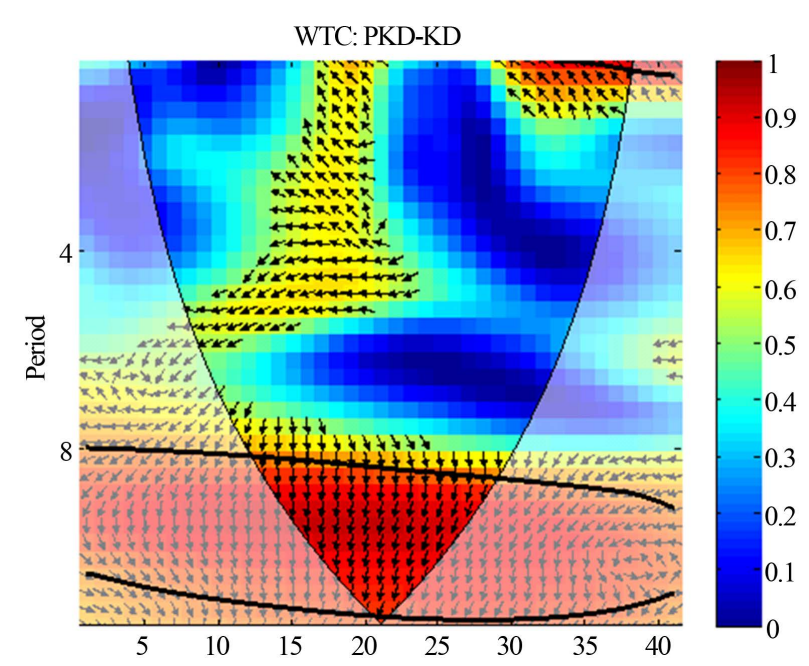

Figure 8. Wavelet coherence between PRD and KD.

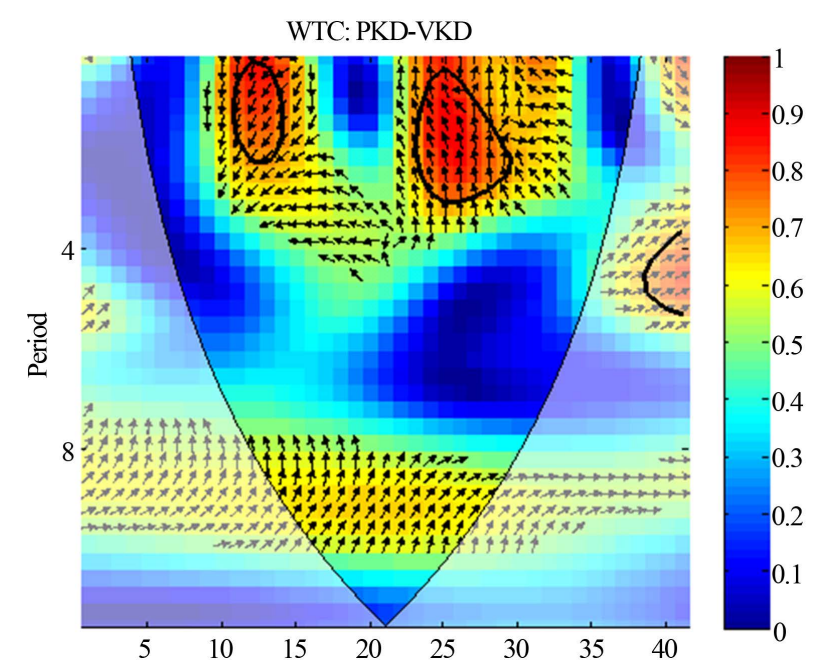

Figure 9. Wavelet coherence between PRD and VKD.

So we can say that setting rates on loans and deposits is, above all, given the current conditions of each institutional unit within the banking system. At the same time the impact of market factors evident only in the long term. However, for next to Figure 5 of ignoring the current market leverage on the formation of interest rates may affect the current stability of the banking system, which in turn has a greater chance of becoming a more significant banking crisis. This is observed in Ukraine in recent years.

There is a similar discrepancy in the formation of interest rates on loans and deposits according to market and leverage affects formation of scale deposits and loans of the banking system (Figure 9). As a result we can identify both periods of significant outflow of deposits and long periods of moderate inflows of resources on deposit accounts, declines in lending in real economy and the growth of bad loans [1] [24] [25].

\section{Conclusions}

The results of the study can determine the appropriate application of wavelet analysis methodology as disclosure of wavelet coherency between the studied data series as a tool for the study on stability of the banking system.

Application of wavelet coherence analysis for the stability of the banking system can not only explore the manifestations of such stability or instability of the banking system, but also emphasize and reveal existing conditions to ensure the efficiency of the banking system.

In particular the work states that among the factors influencing the stability of the banking system in Ukraine 
great role is played by:

lack of capital;

increase in non-performing loans;

lack of prudence rooted policy for setting remuneration of banking activities in the form of interest or in the form of commission income and expenditure;

lack of liquid assets in case of immediate need short-term repayment obligations;

lack of conformity productivity of its workers to expenses aimed at staff retention;

incomplete compliance of market leverage on the formation of the current values of interest rates on loans and deposits.

At the same time we observed that the use of wavelet coherence analysis data series which allowed summarizing stability of the banking system allowed drawing conclusions about reasonable adjustments of dynamics of the components of the studied data series and forming a balanced policy impact on the banking system.

\section{References}

[1] Ahmad, M.A., Kots, G.P. and Lyashenko, V.V. (2015) Bank Lending Efficiency in the Real Sector of the Economy of Ukraine within the Period of 2011 to 2014 Years. Modern Economy, 6, 1209-1218. http://dx.doi.org/10.4236/me.2015.612114http://dx.doi.org/10.1080/00036840601007286

[2] Arif, A. and Nauman Anees, A. (2012) Liquidity Risk and Performance of Banking System. Journal of Financial Regulation and Compliance, 20, 182-195. http://dx.doi.org/10.1108/13581981211218342

[3] Bruno, V. and Shin, H.S. (2015) Capital Flows and the Risk-Taking Channel of Monetary Policy. Journal of Monetary Economics, 71, 119-132. http://dx.doi.org/10.1016/j.jmoneco.2014.11.011

[4] Kuzemin, A. and Lyashenko, V. (2008) Analysis of Spatial-Temporal Dynamics in the System of Economic Security of Different Subjects of Economic Management. International Journal Information Technologies and Knowledge, 2, 234-238.

[5] Minoiu, C. and Reyes, J.A. (2013) A Network Analysis of Global Banking: 1978-2010. Journal of Financial Stability, 9, 168-184. http://dx.doi.org/10.1016/j.jfs.2013.03.001http://dx.doi.org/10.1016/0304-3878(86)90053-2

[6] International Monetary Fund Staff (2008) Financial Soundness Indicators: Compilation Guide. International Monetary Fund.

[7] Gorodnichenko, Y. and Schnitzer, M. (2013) Financial Constraints and Innovation: Why Poor Countries Don’t Catch up. Journal of the European Economic Association, 11, 1115-1152. http://dx.doi.org/10.1111/jeea.12033

[8] Gourinchas, P.O. and Jeanne, O. (2013) Capital Flows to Developing Countries: The Allocation Puzzle. The Review of Economic Studies, 80, 1484-1515. http://dx.doi.org/10.1093/restud/rdt004

[9] Ati, I.A. (2015) Tunisian Banking System Distress and Fragility: An Empirical Study. Journal of Finance, 3, 87-92. http://dx.doi.org/10.15640/jfbm.v3n2a8

[10] She, J.F. and Li, M.X. (2013) Research on the Mechanism and Conditions of the System Stability of the Banking under the Competition Effect. In: Qi, E.S., Shen, J. and Dou, R.L., Eds., International Asia Conference on Industrial Engineering and Management Innovation (IEMI2012), Springer Berlin, Heidelberg, 1717-1725. http://dx.doi.org/10.1007/978-3-642-38445-5 181

[11] Liu, H., Molyneux, P. and Wilson, J.O. (2013) Competition and Stability in European Banking: A Regional Analysis. The Manchester School, 81, 176-201. http://dx.doi.org/10.1111/j.1467-9957.2011.02285.x

[12] Schaeck, K. and Cihák, M. (2014) Competition, Efficiency, and Stability in Banking. Financial Management, 43, 215241. http://dx.doi.org/10.1111/fima.12010

[13] Wang, K., Huang, W., Wu, J. and Liu, Y.N. (2014) Efficiency Measures of the Chinese Commercial Banking System Using an Additive Two-Stage DEA. Omega, 44, 5-20. http://dx.doi.org/10.1016/j.omega.2013.09.005

[14] Anginer, D. and Demirguc-Kunt, A. (2014) Has the Global Banking System Become More Fragile over Time? Journal of Financial Stability, 13, 202-213. http://dx.doi.org/10.1016/j.jfs.2014.02.003

[15] Kingsbury, N. (1999) Image Processing with Complex Wavelets. Philosophical Transactions of the Royal Society of London A: Mathematical, Physical and Engineering Sciences, 357, 2543-2560. http://dx.doi.org/10.1098/rsta.1999.0447

[16] Heil, C.E. and Walnut, D.F. (1989) Continuous and Discrete Wavelet Transforms. SIAM Review, 31, 628-666. http://dx.doi.org/10.1137/1031129

[17] Delbeke, L. and Abry, P. (2000) Stochastic Integral Representation and Properties of the Wavelet Coefficients of Linear Fractional Stable Motion. Stochastic Processes and Their Applications, 86, 177-182. 
http://dx.doi.org/10.1016/S0304-4149(99)00092-7

[18] Veitch, D., Flandrin, P., Abry, P., Riedi, R. and Baraniuk, R. (2002) The Multiscale Nature of Network Traffic: Discovery, Analysis, and Modelling. IEEE Signal Processing Magazine, 19, 28-46. http://dx.doi.org/10.1109/79.998080

[19] Lyashenko, V., Deineko, Z. and Ahmad, A. (2015) Properties of Wavelet Coefficients of Self-Similar Time Series. International Journal of Scientific and Engineering Research, 6, 1492-1499.

[20] Aguiar-Conraria, L. and Soares, M.J. (2011) Oil and the Macroeconomy: Using Wavelets to Analyze Old Issues. Empirical Economics, 40, 645-655. http://dx.doi.org/10.1007/s00181-010-0371-x

[21] Fan, Y. and Gençay, R. (2010) Unit Root Tests with Wavelets. Econometric Theory, 26, 1305-1331. http://dx.doi.org/10.1017/S0266466609990594

[22] Torrence, C. and Webster, P.J. (1999) Interdecadal Changes in the ENSO-Monsoon System. Journal of Climate, 12, 2679-2690. http://dx.doi.org/10.1175/1520-0442(1999)012<2679:ICITEM>2.0.CO;2

[23] Grinsted, A., Moore, J.C. and Jevrejeva, S. (2004) Application of the Cross Wavelet Transform and Wavelet Coherence to Geophysical Time Series. Nonlinear Processes in Geophysics, 11, 561-566. http://dx.doi.org/10.5194/npg-11-561-2004

[24] Lyashenko, V. (2014) Efficiency of Bank Crediting of Real Sector of Economy in the Context of Separate Banking Groups: An Empirical Example from Ukraine. International Journal of Accounting and Economics Studies, 2, 74-79. http://dx.doi.org/10.14419/ijaes.v2i2.3064

[25] Vasyurenko, O., Lyashenko, V. and Podchesova, V. (2014) Efficiency of Lending to Natural Persons and Legal Entities by Banks of Ukraine: Methodology of Stochastic Frontier Analysis. Herald of the National Bank of Ukraine, 1, 511.

\section{Submit or recommend next manuscript to SCIRP and we will provide best service for you:}

Accepting pre-submission inquiries through Email, Facebook, LinkedIn, Twitter, etc.

A wide selection of journals (inclusive of 9 subjects, more than 200 journals)

Providing 24-hour high-quality service

User-friendly online submission system

Fair and swift peer-review system

Efficient typesetting and proofreading procedure

Display of the result of downloads and visits, as well as the number of cited articles

Maximum dissemination of your research work

Submit your manuscript at: http://papersubmission.scirp.org/ 